\title{
Um estudo sobre a utilização de sete papéis distintos no facing de pintura a óleo sobre tela
}

\author{
Patrícia Varela, Matteo Rosi Doria, Ana Bailão
}

\begin{abstract}
Resumo: Será que o papel japonês é o material mais adequado para o facing de pintura sobre tela? Seria benéfica a utilização de papéis específicos adequados a cada caso? Este estudo procurou dar resposta a estas questões e dar a conhecer, dos papéis testados, qual o mais adequado ao facing em pintura a óleo sobre tela. Para o efeito, foram executadas maquetes, de três cores diferentes. Em cada cor foram realizadas duas texturas, uma lisa e outra empastada. Foram também definidas, em cada cor e textura, três áreas: duas para aplicação de dois vernizes distintos e outra para permanecer sem verniz. As maquetes foram realizadas para que se obtivessem todas as combinações dos materiais anteriormente descritos e cada papel foi testado em cada uma destas combinações.
\end{abstract}

Realizados os ensaios e analisados os resultados, concluiu-se que, dos materiais testados, o papel japonês nem sempre foi o mais eficaz, tendo sido superado pelo Wet-strength Tissue, um papel celulósico, por demonstrar facilidade de aplicação, pela resistência do papel e pela perda de fibras.

Palavras-chave: facing, pintura a óleo, wet-strength tissue, modelspan

\section{A study on the use of seven different papers on the facing of oil easel painting}

Abstract: Is japanese paper the most suitable material for facing on easel paintings? Would it be beneficial to use specific papers appropriate to each case? This study sought to answer these questions and determine, from the tested papers, which is the most suitable for the facing on oil easel paintings. For this purpose, models were made, in three different colors. In each color, two textures were made, textures and not textured. Three areas were also defined, in each color and texture: two do apply two different varnishes and one to remain without varnish. The models were made so that all combinations of materials previously described were obtained and each paper was tested in each of these combinations.

After the tests were carried out and the results were analyzed, it was concluded that, of the tested materials, Japanese paper was not always the most effective, having been surpassed by Wet-strength Tissue, a cellulosic paper, for demonstrating ease of application, due to the paper strength and fiber loss.

Keywords: facing, oil painting, wet-strength tissue, modelspan

\section{Estudio sobre el uso de siete papeles diferentes para facing en pintura al óleo sobre lienzo}

Resumen: ¿Es el papel japonés el material más adecuado al facing en pintura sobre lienzos? ¿Sería beneficioso utilizar papeles especíicos apropiados para cada caso? Este estudio buscó responder a estas preguntas y dar a conocer, a partir de los papeles probados, cuál es el más adecuado al facing de pintura al óleo sobre lienzo. Para este fin, se hicieron modelos, en tres colores diferentes. En cada color se realizaron dos texturas, una lisa y otra empastada. En cada color y textura también se definieron tres zonas: dos para aplicar dos barnices diferentes y una para permanecer sin barniz. Los modelos se realizaron con el fin de obtener todas las combinaciones de los materiales descritos anteriormente y cada papel fue probado en cada una de estas combinaciones.

Realizadas las pruebas y analizados los resultados, se concluyó que, de los materiales ensayados, el papel japonés no siempre fue el más eficaz, habiendo sido superado por Wet-Strength Tissue, un papel celulósico, para demostrar facilidad de aplicación, debido a la resistencia del papel y la pérdida de fibras.

Palabras clave: facing, pintura al oleo, wet-strength tissue, modelpan 


\section{Papel japonés}

O papel japonês (washi) (Mizumara 2015: 45) começou a ser utilizado, no Oeste, no século XVII (Grantham 2002 :29), principalmente devido à sua beleza (Wada 2008 :55). Em 1970 foi descoberto como ferramenta para a conservação e restauro. As suas qualidades fizeram com que fosse utilizado em grande escala, também no Ocidente, na conservação e restauro dos mais variados objetos (Grantham 2002: 29).

A produção manual de papel japonês tem vindo a ser realizada, ao longo dos séculos, por algumas famílias como uma fonte de renda extra no final do ano, quando termina a colheira do arroz. É uma atividade exercida em casa, pelos membros da família, e passada de geração em geração com ligeiras alterações (Fuguel 2016: 74).

No entanto, a sua produção tem vindo a diminuir ao longo dos tempos (Wada 2008: 55), sendo que das 100.000 oficinas ativas no século XIX, uma pequena minoria se mantém (Grantham 2002: 33). A principal razão para que isto aconteça deve-se à industrialização desta prática (Colbourne 2015: 158), possibilitando uma produção mais rápida e, consequentemente, de menor custo.

\section{-Matéria-prima}

As fibras são a matéria-prima mais importante na produção de papel japonês, porém outros materiais também desempenham uma grande função, como a água, o agente alcalino (Wada 2008: 59) e o neri, que altera a viscosidade da água e, consequentemente, ajuda na produção de um papel mais forte.

As plantas mais utilizadas na extração de matéria-prima para o fabrico de papel japonês são o kōzo, o mitsumata e o gampi (Wada 2008: 58). O seu uso deve-se à facilidade de cultivo destas plantas e à sua vasta produção no Japão. Destaca-se ainda o facto de estas espécies produzirem uma grande quantidade de fibras facilmente separáveis, favorecendo a produção de um papel de boa qualidade (Grantham 2002: 29).

Das três plantas referidas anteriormente, a primeira a ser utilizada na produção de papel japonês foi o kōzo (Wada 2008 e:58), um arbusto de folha caduca da família Moraceae (Masuda 2010: 32). É facilmente cultivável em qualquer terreno (Masuda 2010: 32) e, das três, é a que cresce mais rapidamente (Grantham 2002: 29), chegando a atingir os 6 metros em estado selvagem, mas apenas 1,5 a 1,8 metros quando cultivada, visto que é cortada todos os anos (Masuda 2010: 32), entre dezembro e janeiro (Mizumara 2015: 47).

Se depois de cortado forem deixadas as raízes [figura 1], o arbusto volta a crescer, sendo possível fazer-se uma nova colheita no ano seguinte (Mizumara 2015: 47).

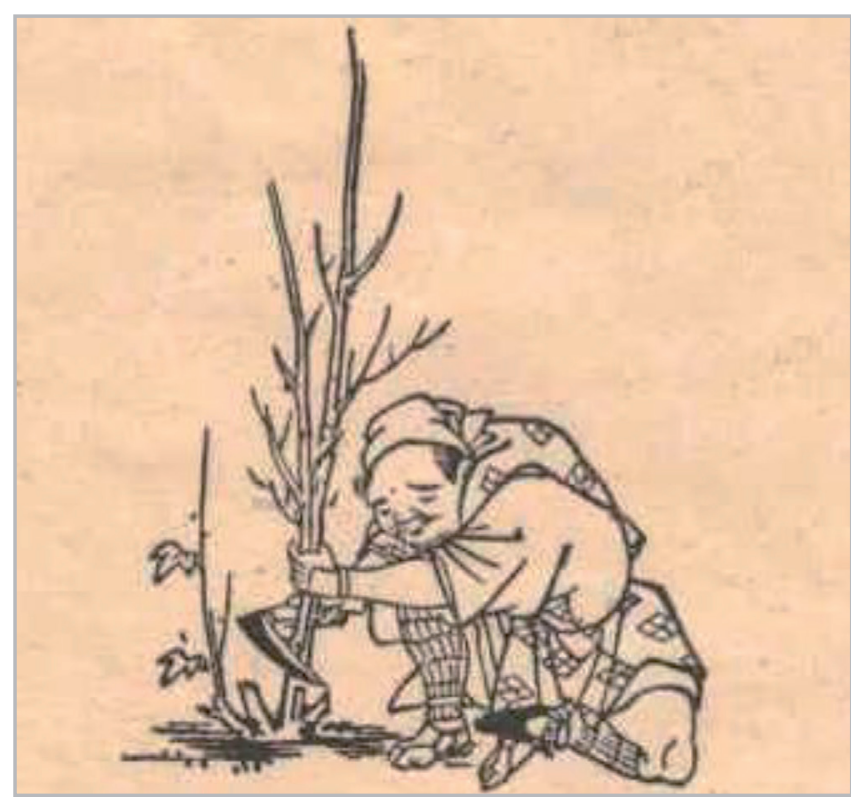

Figura 1.- Colheita de ramos para produção de papel japonês. Fonte: https://bit.ly/2E8YO9| [consultada a 05/08/2020].

Detém fibras grossas, fortes, resistentes e longas, que chegam a alcançar os 12 milímetros de comprimento, possibilitando a produção de um papel fino sem que, no entanto, haja perda de força. Estas características fazem com que o papel japonês de kōzo seja muito utilizado por conservadores-restauradores no Ocidente, mesmo quando não se tem a certeza de que será o material mais indicado (Grantham 2002 f:29). Um közo com idade superior a um ano, denominado por "ya-közo", produz um papel de inferior qualidade (Wada 2008: 58).

O mitsumata e o gampi começaram a ser utilizados mais tarde que o kōzo (Grantham 2002 g:29). Produzem papel fino e suave, mas relativamente caro, especialmente o gampi por ser mais difícil de cultivar e existir em maior quantidade no estado selvagem nas montanhas (Wada 2008:59).

O mitsumata é um arbusto de folha caduca (Wada 2008 :59), da família Thymelaeaceae (Masuda 2010: 32). Só é possível fazer a sua colheita em ciclos de 2 a 5 anos (Grantham 2002: 29). Dispõe de fibras finas e curtas (Wada 2008: 59) que atingem, aproximadamente, os 3 milímetros de comprimento (Grantham 2002: 29).

Também o gampi é um arbusto de folha caduca da família Thymelaeaceae. Apresenta fibras finas e curtas (Wada 2008: 59) (aproximadamente 4 milímetros) (Grantham 2002: 29).

É comum fazer-se a mistura de fibras de mitsumata e gampi na polpa de kōzo de forma a dar-lhe diferentes qualidades (Grantham 2002: 29).

Segundo Minako Wada (2008), 80 \% do papel japonês é produzido com fibras de kōzo (Wada 2008: 58), no entanto, 
outras fibras vegetais, tais como cânhamo de Manila, bambu e palha de arroz, são utilizadas na produção de papel japonês (Mizumara, Kubo, Moriki 2015:45).

\section{Facing}

O facing ${ }^{[1]}$, empapelado, empapelamento ou faceamento, consiste num sistema de proteção temporário (Giannini, Roani 2008: 76) em que se cobre a camada pictórica de uma obra fazendo aderir um papel protetor com um adesivo adequado às suas características [Figura 2].

Este sistema de proteção tem a capacidade de salvaguardar a camada pictórica, atuando também como consolidante e/ou fixante, dependendo das situações, das zonas em destacamento, permitindo a realização de outros tratamentos na obra (Doria 2013:8). A aplicação do facing implica ainda uma limpeza subsequente da superfície da pintura, uma vez que, depois de retirado, o adesivo empregue deve ser removido (Alba, Martín-Rey, Doménech-Carbó 2019).

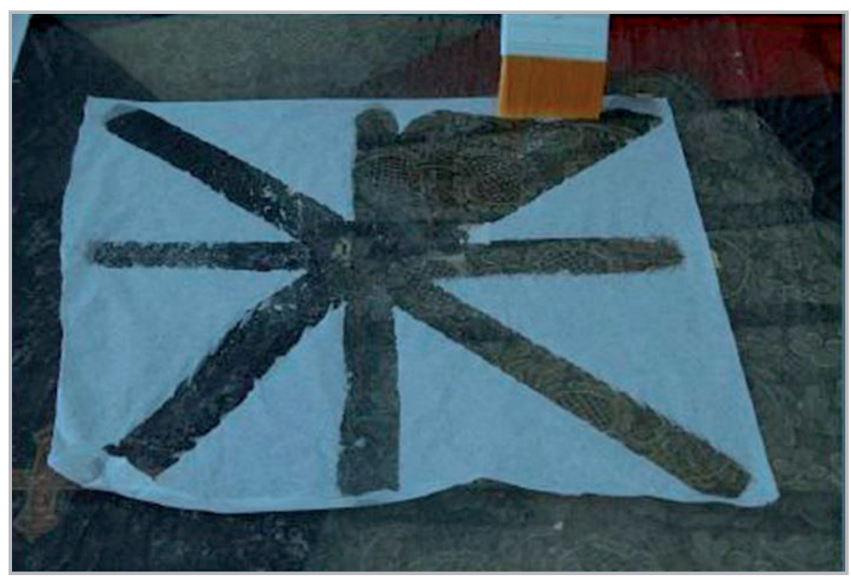

Figura 2.- Aplicação do facing numa pintura sobre tela. Ana Bailão@

\section{- Finalidades}

O facing pode ter várias finalidades quando utilizado corretamente:

- Antes de executar quaisquer tratamentos na obra para prevenir danos durante procedimentos como a limpeza ou o tratamento do suporte (Villarquide 2005: 155);

- Quando se tem uma obra com a camada pictórica muito vulnerável e existe a necessidade de movê-la ou realizar tratamentos que exijam a sua manipulação. A aderência entre a camada pictórica e o suporte são favorecidos pelo facing, mantendo-os intactos (Sánchez 2012: 148);

- Em caso de destacamento pontual da camada pictórica o facing pode ser aplicado apenas nas zonas problemáticas promovendo a fixação entre os estratos

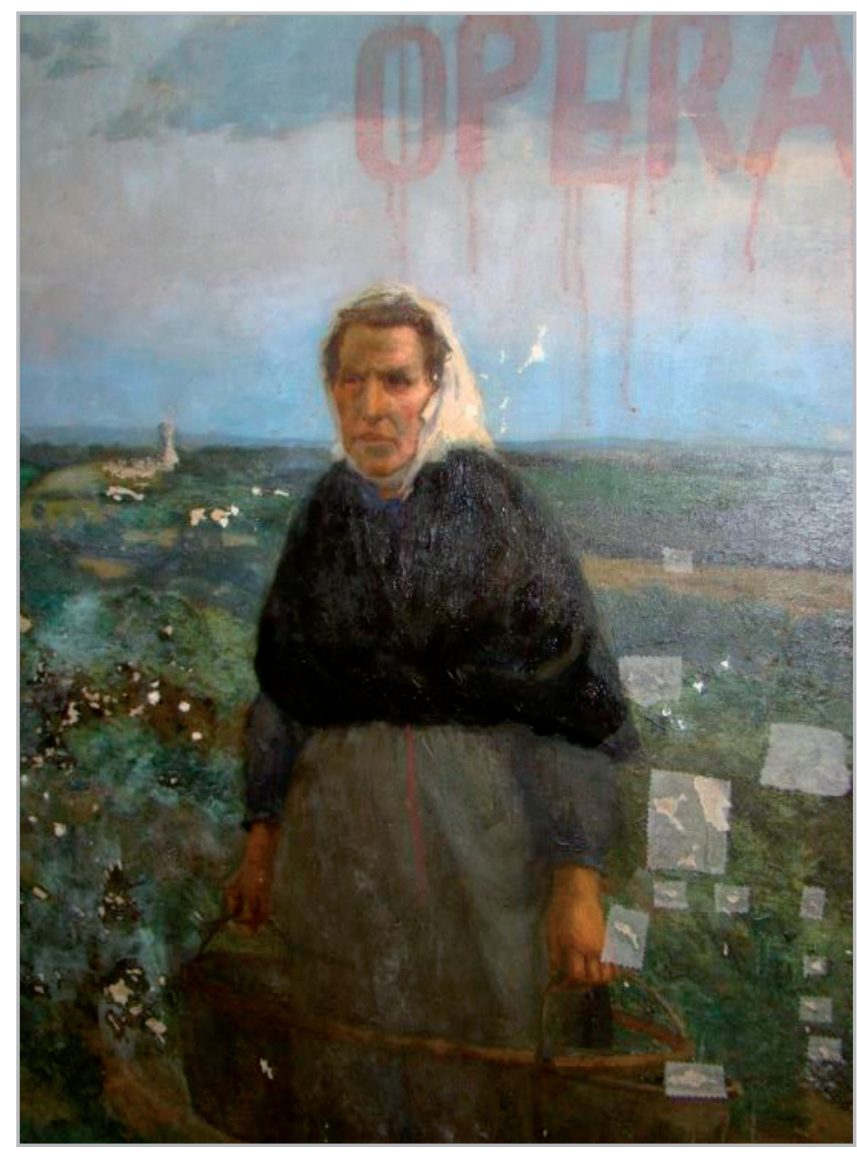

Figura 3.- Aplicação do facing em zonas pontuais. Ana Bailão@

(Stoner, Rushfield 2012: 374-375) [Figura 3];

- O facing permite realizar consolidações e fixações da obra, por conferir coesão ao estrato pictórico para além de o aderir ao suporte. Para uma penetração mais profunda, e nas situações em que se opte por um adesivo termoplástico, pode ser reativado com calor. Porém, este sistema pode ter alguns inconvenientes, uma vez que a penetração do adesivo não é feita de forma homogénea, mas apenas nas zonas onde se encontram as fissuras e destacamentos da camada pictórica (Villarquide 2005: 155-156);

- Também permite o nivelamento da obra, uma vez que, ao secar, o papel celulósico contrai ligeiramente. Isto vai também depender do adesivo utilizado. As colas animais são as principais responsáveis por esta retração (Villarquide 2005: 155-156).

Impedir a penetração do adesivo na estrutura original da pintura é uma tarefa muito complicada, se não inevitável (Calvo 2012 a:250), levantando dúvidas acerca da utilização do facing, visto não ser um método removível. No entanto, sem o facing alguns tratamentos poderiam ser significativamente mais arriscados ou até impossíveis de realizar (Sánchez 2012: 148).

É ainda importante que, antes de executar o facing, o conservador-restaurador saiba, através de testes e observação, como o aplicar (Calvo 2012: 250) e retirar, 
sem causar danos na pintura (Rodgers 1988: 14). Ou seja, sem deixar resíduos na superfície da obra, sem reverter a adesividade do adesivo (Stoner 2012: 375) e sem interferir com a camada pictórica, o verniz ou a técnica utilizada pelo artista.

No entanto, nem sempre existe necessidade de fazer um facing e, por vezes, fazê-lo pode até ser danoso para a obra (Villarquide 2005: 163). Segundo Ana Villarquide (2005), não se deve fazer o facing nas seguintes situações:

- Quando se trata de uma obra a têmpera sem verniz;

- Quando a obra não tem verniz e existe a possibilidade de alterações da cor;

- Quando a obra é composta por colagens de papel, madeira, ferros, ou materiais que se comportem de forma distinta entre si (VILLARQUIDE 2005: 163).

\section{Ensaios experimentais}

Os ensaios experimentais foram realizados na empresa privada Conservazione Beni Culturali (C.B.C.), em Roma, sob orientação do Professor Matteo Rossi Doria, especialista na conservação e restauro estrutural de pinturas sobre tela.

\section{- Objetivos}

O papel japonês tem vindo a ser correntemente utilizado como material em conservação e restauro (Grantham 2002 l:29), nomeadamente no facing de pinturas sobre tela. Apesar disto, verifica-se escassez de informação e investigação sobre este tema. Grande parte dos conservadores-restauradores de pintura de cavalete recorrem, assim, aos papéis japoneses mais acessíveis ou disponíveis no mercado, independentemente da sua utilização específica, ainda que alguns possam ter as suas próprias preferências provenientes da prática profissional.

Importa ainda referir que, contrariamente àquilo que é a prática mais comum, a utilização do papel japonês alguns profissionais da área já publicaram artigos em que afirmam e justificam a sua preferência por materiais alternativos para este fim (Nicola et al. 1973: 177-179; Doria 2013: 7791).

Será que o papel japonês é o material mais adequado para o facing de pintura sobre tela? Seria benéfica a utilização de papéis específicos adequados a cada caso?

Dadas as circunstâncias, esta investigação tem como objetivo geral, procurar identificar qual o papel japonês mais adequado ao facing de pinturas a óleo sobre tela. Pretendemos ainda:

- Analisar o comportamento dos papéis quando submetidos a diferentes tipos de texturas, adesivos e solventes;
- Conhecer as razões fundamentais para a utilização do papel japonês no facing em detrimento de outros materiais;

- Determinar se o papel japonês é, de facto, a melhor opção para a realização do facing em pinturas de cavalete.

\section{- Metodologia e materiais}

Para os ensaios foram preparadas maquetes, uma vez que a metodologia utilizada na aplicação dos diferentes papéis poderia danificar pinturas reais. Isto porque a utilização de diferentes papéis e adesivos, numa mesma pintura, poderiam gerar danos, como marcas na superfície da pintura, tensões, entre outros.

Para a elaboração das maquetes foi utilizada uma tela de linho com uma preparação de óxido de zinco com aglutinante acrílico. A tela foi recortada, tendo em conta o tamanho desejado para as amostras de papel, e foi agrafada a placas de madeira.

De seguida, as telas foram pintadas, com o auxílio de uma trincha e de uma espátula, com três cores a óleo da marca Sennelier - Preto de Marfim (Ivory Black) com a composição.(PBk9/PBk7)[2], Branco de Titânio (Titanium White) constituído por (PW6/PW4) ${ }^{[3]}$, Azul de Cobalto (Cobalt Blue Hue) composto pela mistura de pigmentos (PB29/PB15:3/PW6 ${ }^{[4]}$ - diluídas em essência de terebintina para se obter maior fluidez e para facilitar a secagem. Escolheram-se as tintas a óleo da marca Sennelier por terem uma secagem mais rápida que as concorrentes. Após duas semanas, já secas ao tato, as maquetes foram envernizadas com dois vernizes distintos - 004 Retouching Varnish da Talens e Laropal ${ }^{\circledR} \mathrm{A} 81$ - este último produzido com $20 \mathrm{~g}$ de Laropa $l^{\circledR} \mathrm{A} 81$ dissolvido em $120 \mathrm{ml}$ de ligroína $100-140^{\circ} \mathrm{C}$ e $5 \mathrm{ml}$ de acetato de butilo. Escolheu-se a ligroína por ser de baixa toxicidade. Todavia, por ser necessário um solvente de media polaridade para auxiliar a dissolução da resina, optou-se pelo acetato de butilo.

As maquetes foram executadas para que se obtivessem todas as combinações de materiais possíveis. Para cada cor, foram produzidas duas texturas (uma lisa e outra empastada) e em cada uma destas texturas criaram-se três zonas: em duas aplicaram-se dois vernizes (004 Retouching Varnish da Talens e Laropal ${ }^{\circledR}$ A81) e a terceira zona ficou sem verniz [Figura 4]. Esta opção por manter uma superfície sem verniz deve-se ao facto de ser uma realidade da pintura contemporânea.

A utilização de diferentes texturas e vernizes, tinha por objetivo analisar o comportamento dos diferentes papéis e averiguar se existe um tipo de papel mais adequado a cada textura ou verniz.

Relativamente aos papéis japoneses, foram utilizados seis papéis distintos - Gampi, Mistsumata, Tosa Usushi, 

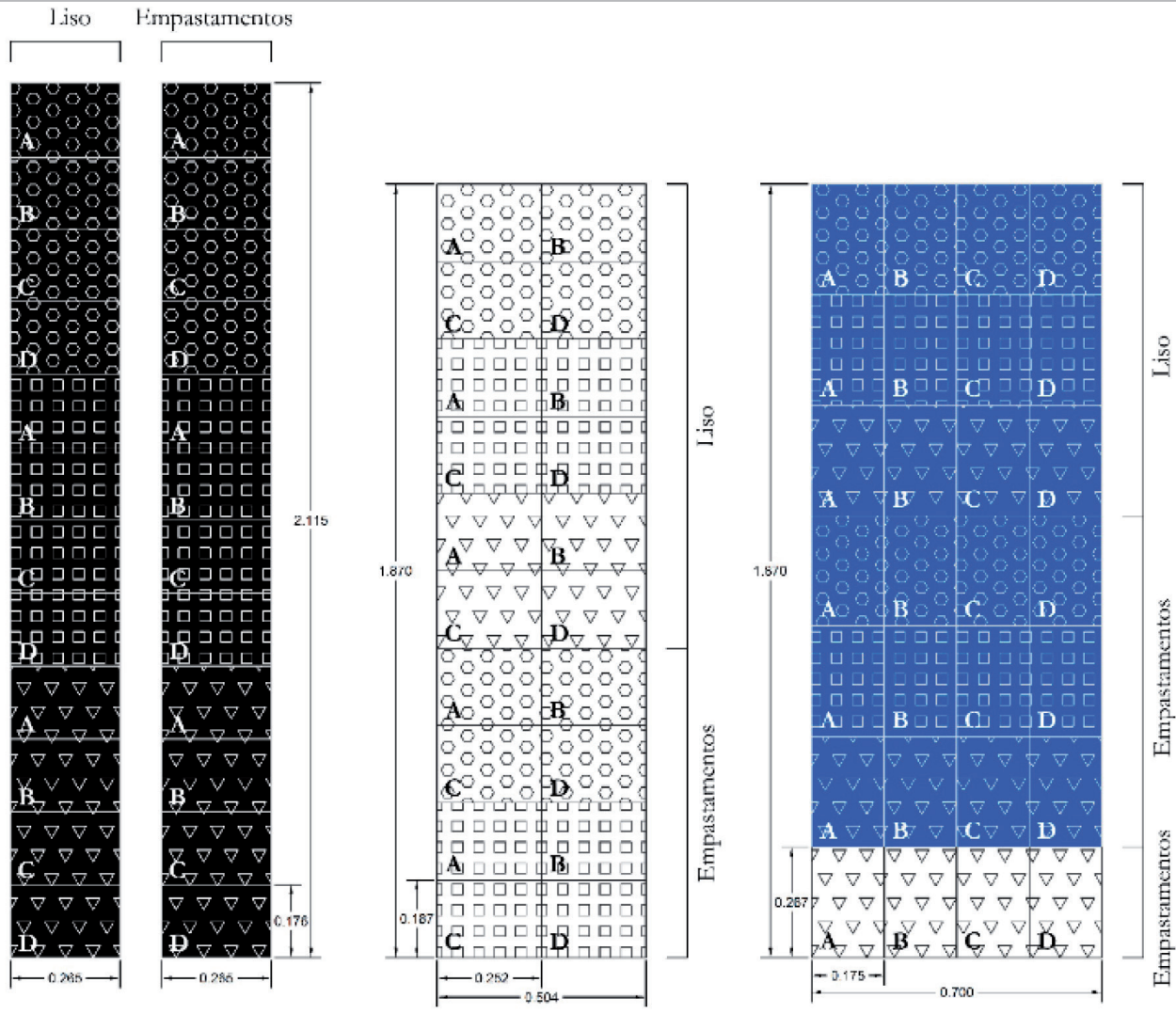

LEGENDA

Tinta a Óleo Sennelier, Preto de Marfim, $\mathrm{PBk} 9$ / PBk7

$\square$ Tinta a Óleos Sennelier, Branco de Titànio, PW6 / PW 4

$\square$ Tinta a Ólco Sennclicr, Axul de Cobalto, PB29 / PB15:3 / PW6

\author{
Fog Sem Verniz \\ 區 Verniz 004 Retouching \\ Varnish, Talens

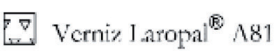

PNo 6

Figura 4.- Esquema das maquetes. As medidas encontram-se indicadas em metros. Patrícia Varela@

Kinugawa Elfenbein, Bib Tengujo, Moldelspan - e ainda uma alternativa ao papel japonês - o Wet-strength Tissue. Foram selecionados papéis com diferentes composições e gramagens entre as $10 \mathrm{~g} / \mathrm{m}^{2}$ e as $22 \mathrm{~g} / \mathrm{m}^{2}$. como se pode ver na tabela 1.0 papel Modelspan foi escolhido por ser muito usado em Portugal para o facing. O Wet-strength Tissue

\begin{tabular}{|c|c|c|c|}
\hline Nome & Composição & Gramagem & Fornecedor \\
\hline Gampi & $100 \%$ Gampi & $10 \mathrm{~g} / \mathrm{m}^{2}$ & Japico \\
\hline Mitsumata & $\begin{array}{c}100 \% \\
\text { Mitsumata }\end{array}$ & $11 \mathrm{~g} / \mathrm{m}^{2}$ & Japico \\
\hline Bib Tengujo & $100 \%$ Manila & $12 \mathrm{~g} / \mathrm{m}^{2}$ & Japico \\
\hline Modelspan & $100 \%$ Manila & $12 \mathrm{~g} / \mathrm{m}^{2}$ & $\begin{array}{l}\text { Produtos de } \\
\text { onservación }\end{array}$ \\
\hline $\begin{array}{l}\text { Wet-strength } \\
\text { Tissue }\end{array}$ & $100 \%$ Celulose & $13 \mathrm{~g} / \mathrm{m}^{2}$ & Bresciani s.r.l. \\
\hline Tosa Usushi & 100 \% Kōzo & $15 \mathrm{~g} / \mathrm{m}^{2}$ & Japico \\
\hline $\begin{array}{l}\text { Kinugawa } \\
\text { Elfenbein }\end{array}$ & $\begin{array}{c}70 \% \text { Kōzo + } \\
30 \% \text { polpa de } \\
\text { celulose }\end{array}$ & $22 \mathrm{~g} / \mathrm{m}^{2}$ & Japico \\
\hline
\end{tabular}

Tabela 1.- Lista de paéis japoneses ulizados. Patricia Varela@ por se apresentar como uma alternativa onde, durante o processo de calandragem ${ }^{[5]}$, são adicionadas pequenas quantidades de fibras de derivados de poliamida, que the conferem uma maior resistência à água (Doria 2013:7). Quanto aos restantes papéis, procurou-se essencialmente obter diversidade e pureza das fibras com as quais o papel foi produzido (kōzo, gampi, mitsumata e manila).

Os papéis foram cortados com dimensões de 7,5 $\mathrm{cm} \times 7,5$ $\mathrm{cm}$. O objetivo era que, em cada uma das combinações de materiais presentes na maquete ( 3 cores $\times 2$ texturas $\times 3$ vernizes/não verniz $=18$ combinações), se testassem os 7 papéis com os 4 adesivos. Assim, no total, cada um dos papéis foi testado em 72 ambientes diferentes (combinação de cores, texturas, vernizes e adesivos), o que requeria 72 amostras de cada um dos 7 papéis, perfazendo um conjunto de 504 observações $(72 \times 7)$.

Inicialmente, com o intuito de perceber quais os adesivos mais indicados para a experiência foram testados o Funoran Solution, o Foam\&Fabric 24 Spray Adhesive, o Antares, as colas de coelho com Bloom ${ }^{[6]}$, de 150, 250 e 350, o BEVA ${ }^{\circledR} 371$, o Tylose ${ }^{\circledast}$ MH 300 e o BEVA 371 BEVA 371. 
Dos anteriores, os adesivos empregues na aplicação do papel japonês para realização do facing foram:

- a cola de coelho, com um Bloom de 250, dissolvida em água numa proporção de 1:12;

- o $B E V A^{\circledast} 371$ dissolvido em ciclohexano numa proporção de 1:4;

- o Tylose ${ }^{\circledR}$ MH 300 dissolvido em água numa proporção de 1:50;

- o Klucel ${ }^{\circledR}$ G dissolvido em água numa proporção de 1:23.

A cola de coelho e o $B E V A^{\circledR} 371$ foram selecionados por serem alguns dos adesivos mais utilizados no facing. No caso do Tylose $^{\circledR}$ e do Klucel $^{\circledR}$, pretendia testar-se adesivos com menor poder adesivo e com dissolução em água.

Em cada combinação de cor, textura e verniz foram aplicados os papéis com diferentes adesivos [Figura 41]. A sua aplicação fez-se pincelando cada amostra de papel, já sobre a superfície pictórica, com o respetivo adesivo.

A remoção dos papéis aplicados com $B E V A^{\circledR} 371$ foi feita com o solvente ciclohexano enquanto, para os outros adesivos, foi utilizada água morna. Em todos os casos a remoção foi feita com o auxílio de uma esponja embebida do respetivo solvente.

Durante a aplicação foram avaliadas, numa escala de 1 a 5, as seguintes variáveis:

a) a quantidade de bolhas que se formavam (1 - imensas; 5 - nenhumas);

b) a perda de fibras do papel aquando da passagem do adesivo (1 - imensas; 5 - nenhumas);

c) a facilidade, em geral, da aplicação (1 - extremamente difícil; 5 - extremamente fácil).

Após a administração do adesivo foi observado, também numa escala de 1 a 5, o seguinte:

a) a opacidade (1 - completamente opaco; 5 completamente translúcido);

b) a aderência (1 - pouco aderente; 5 - muito aderente); c) a quantidade de passagens necessárias com a esponja (1 - elevado número de passagens; 5 - reduzido número de passagens);

d) a resistência do papel ( 1 - desfaz-se completamente;

5 - sai por inteiro);

e) os resíduos de cola ( 1 - imensos; 5 - nenhuns);

f) os resíduos de fibras (1 - imensos; 5 - nenhuns);

g) a limpeza (1 - extremamente difícil; 5 - extremamente fácil);

h) as marcas/manchas ( 1 - imensas; 5 - nenhumas).

É de notar que, embora as escalas possam ter diferentes significados para os extremos (1 e 5), verifica-se que 1 corresponde sempre ao comportamento máximo negativo, enquanto o 5 corresponde sempre ao comportamento máximo positivo.
Com esta informação, foram, por fim, desenvolvidos gráficos explicativos do comportamento dos diferentes papéis.

\section{- Resultados}

Para a análise dos resultados obtidos na aplicação dos diferentes papéis, foram avaliadas as variáveis acima descritas. Neste sentido, observaram-se diferenças mais significativas no comportamento das combinações papel/ adesivo/textura, no entanto, os resultados a seguir expostos referem-se também às diferentes cores e vernizes/ zona sem verniz.

Na textura lisa, com o adesivo $B E V A^{\oplus} 371$ [Figura 5 a], todos os papéis foram muito fáceis de aplicar e de remover. Ainda assim, o desempenho do Kinugawa Elfenbein foi o menos positivo, uma vez que, depois de seco, a aderência à superfície da pintura foi quase nula, sendo possível fazer a remoção do papel sem a utilização de qualquer solvente. $\mathrm{O}$ único ponto negativo acerca deste adesivo, quando associado aos restantes papéis, foi o facto de, depois de seco, apresentar uma grande opacidade, não sendo possível monitorizar alterações que possam ocorrer na superfície pictórica após a aplicação do facing.

Para as zonas com empastamentos [Figura 5 b], os resultados não se mostraram tão favoráveis com o adesivo $B E V A^{\circledR} 371$. Ao serem aplicados, os papéis não aderiam aos empastamentos, deixando-os, por isso, desprotegidos, o oposto daquilo que se pretende ao realizar o facing.

Relativamente à cola de coelho na textura lisa [Figura 6 a], os papéis que melhores resultados alcançaram foram o Wet-strength Tissue e o Modelspan. Para estes papéis a aplicação foi muito fácil, sem formação de bolhas ou perda de fibras, e com uma aderência bastante boa para aquilo que se pretende com o facing. Ainda assim, o Wet-strength Tissue destaca-se pelo facto de largar muito poucas fibras aquando da sua remoção, um ponto muito positivo quando se faz o tratamento de superfícies amplas, facilitando no trabalho de limpeza.

Se o objetivo for obter uma aderência muito forte e poucos resíduos de cola após a remoção, o Kinugawa Elfenbein também seria uma boa opção, visto que, devido à sua gramagem $\left(22 \mathrm{~g} / \mathrm{m}^{2}\right)$, este papel consegue absorver bastante adesivo, fazendo com que adira melhor à superfície. Contudo, durante a remoção, vai existir maior resistência.

No que respeita à opacidade, a cola de coelho, em geral, permite que se consiga uma boa observação da superfície pictórica depois da aplicação do facing, Com piores resultados neste aspeto temos o Kinugawa Elfenbein e o Tosa Usushi, os papéis com mais gramagem.

Os papéis com gramagens mais baixas, como o Gampi, o Mitsumata e o Bib Tengujo são menos resistentes, rasgandose em vários bocados ao serem removidos. 
A cola de coelho, apesar de deixar bastantes resíduos, é fácil de limpar com água, não deixando quaisquer marcas ou manchas na superfície pictórica.

No que concerne à utilização da cola de coelho em zonas de empastamentos [Figura 6 b)], podemos ver o excelente desempenho do Bib Tengujo que se destacou pela aderência em zonas de empastamentos altos ( $\geq 3 \mathrm{~mm}$ ), sem formação de bolhas. Durante a remoção a folha desfez-se bastante, no entanto, devido à facilidade de aplicação e à sua ótima aderência, este foi considerado o melhor papel para situações em que temos empastamentos altos.

Para obras com empastamentos baixos ( $<3 \mathrm{~mm}$ ), o Wetstrength Tissue o o Modelspan são boas opções. Estes papéis são fáceis de aplicar, largam poucas fibras e, durante a remoção, têm a vantagem de sair facilmente, rasgando muito pouco.

Ao contrário daquilo que acontecia na textura lisa, devido à sua forte adesividade, o Kinugawa Elfenbein torna-se uma má escolha para as zonas com empastamentos. Isto porque, ao passar a esponja para remoção do papel, foi necessário aplicar muita força para que fosse retirado, o que colocava os empastamentos em risco de destacamento.

No que diz respeito ao adesivo $\mathrm{Kluce}^{\circledR} \mathrm{G}$, quando aplicado em zonas lisas [Figura 7 a)], pode-se observar que, mais uma vez, os papéis Wet-strength Tissue e Modelspan são os mais adequados. Apresentaram grande facilidade de aplicação, sem perda de fibras e sem formação de bolhas. A remoção foi efetuada sem a necessidade de muitas passagens da esponja. Os papéis saíram sem rasgar. Relativamente à aderência, todos os papéis se encontram no mesmo patamar, à exceção do Kinugawa Elfenbein (22 $\mathrm{g} / \mathrm{m}^{2}$ ), que devido à sua elevada gramagem combinada com a viscosidade do adesivo não o conseguiu absorver, nem o transmitiu à superfície da pintura, como os restantes papéis.

Em relação à opacidade, temos um adesivo que não possibilita a visualização da camada pictórica após a aplicação do facing, sendo este fator mais evidente nos papéis Tosa Usushi, Kinugawa Elfenbein e Bib Tengujo.

Mais uma vez, nas zonas de empastamentos [Figura 7 b)], podemos verificar que o Bib Tengujo, apesar da sua fraca resistência ao ser removido, foi o melhor papel. Distinguiuse, principalmente, pela aderência, na medida em que se moldava perfeitamente aos empastamentos mais altos, aderindo em todos os ângulos. O Wet-strength Tissue e o Modelspan mantêm-se, tal como para a cola de coelho, os papéis mais indicados para empastamentos baixos, proporcionando uma remoção mais facilitada por saírem quase sem rasgar.

Quanto à utilização do adesivo Tylose ${ }^{\circledast} \mathrm{MH} 300$ na zona lisa, pode constatar-se que o Wet-strength Tisseu e o Modelspan são os mais apropriados, assim como o Tosa Usushi que, apesar de se ter mantido, até agora, entre os piores papéis, com este adesivo acaba por se destacar pela positiva.

O Tylose ${ }^{\circledast}$ MH 300 tem fraca aderência à superfície pictórica, como se pode observar na figura 8 a). No entanto, pelo que se pôde observar durante a experiência, a aderência é suficiente para situações em que é preciso fazer o transporte de uma pintura de um local para outro ou quando a pintura não se encontra num estado de conservação muito crítico.

Devido à sua grande perde de fibras aquando da passagem do pincel com adesivo o Mitsumata rasga bastante.

Já na zona de empastamentos [Figura 8 b)], temos, mais uma vez, o Bib Tengujo como o mais indicado, seguido do Wet-strength Tissue e do Modelspan.

Em geral, a limpeza dos resíduos, depois da remoção do facing, foi muito fácil para todos os papéis e adesivos. Não se verificou a existência de manchas ou marcas, como alterações de cor. Mas constatou-se que, devido ao pouco tempo de secagem das maquetes, permaneceu uma delimitação ligeira correspondente ao perímetro dos papéis de forma quadrangular

Na figura 9 a) pode verificar-se que, na textura lisa, em média (média de todos os adesivos), o papel Wet-strength Tissue foi o que melhor se comportou. Obtendo-se, valores de 4,5 para as bolhas, 5 para a perda de fibras durante a aplicação do adesivo, 4,5 para a facilidade de aplicação, 3,25 para a opacidade, 3,5 para a aderência, 3,75 para as passagens da esponja, 5 para a resistência do papel, 3 para os resíduos de cola, 4,5 para os resíduos de fibras, e 5 para a limpeza e para as marcas/manchas.

Em relação à textura com empastamentos [Figura 9 b)], destacaram-se principalmente três papéis pela positiva: o Bib Tengujo, o Modelspan e o Wet-strength Tissue. Apresentam valores médios equivalentes para as variáveis de resíduos de cola, com 3, limpeza e marcas/ manchas, com 5 , e resíduos de fibras, com 4,5. Na variável bolhas foi o papel Bib Tengujo que obteve melhores resultados, com 4,25 valores. Na variável perda de fibras salientaram-se o Modelspan e o Wet-strength Tissue, com 5. Quanto à facilidade de aplicação e passagens da esponja distinguiram-se os papéis Bib Tengujo e Modelspan, com 3,75 em ambas. Para a variável da resistência do papel, os papéis Modelspan e Wet-strength Tissue, obtiveram uma classificação média, em textura de empastamentos, de 4,25. Já para a opacidade, destacou-se o Gampi, com 3, logo seguido do Mitsumata e do Bib Tengujo, ambos com 2,75 . Na aderência, com grande importância para a textura de empastamentos, realça-se o papel o Bib Tengujo, com 4,25 .

Em relação aos diferentes vernizes/zonas sem verniz aplicados nas distintas cores, não foram observadas diferenças após a aplicação do facing. 


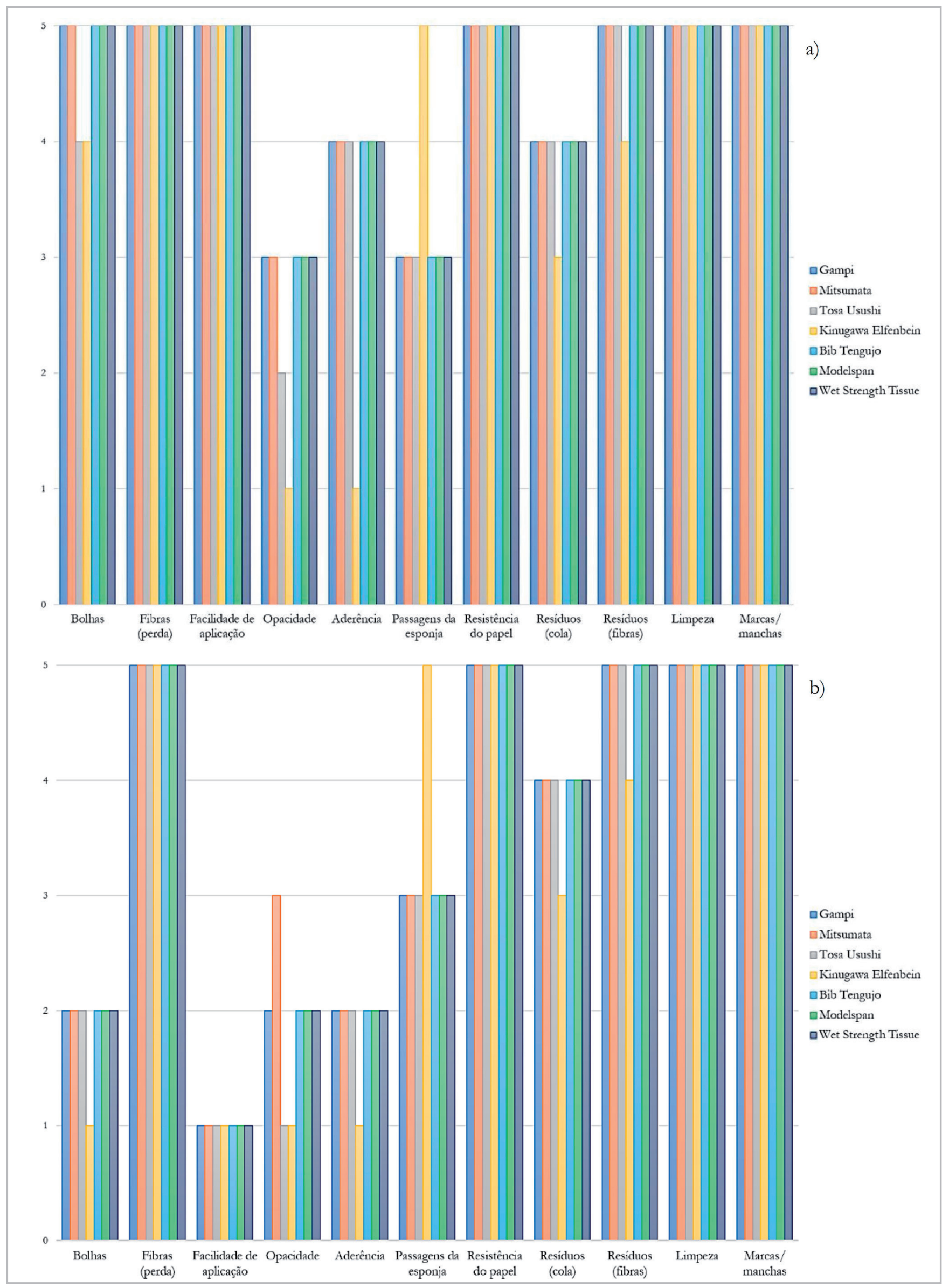

Figura 5.- Resultados obtidos para cada um dos papéis na combinação do adesivo BEVA ${ }^{\oplus} 371$ com as texturas a) lisa, b) com empastamentos. Patricia Varela@ 


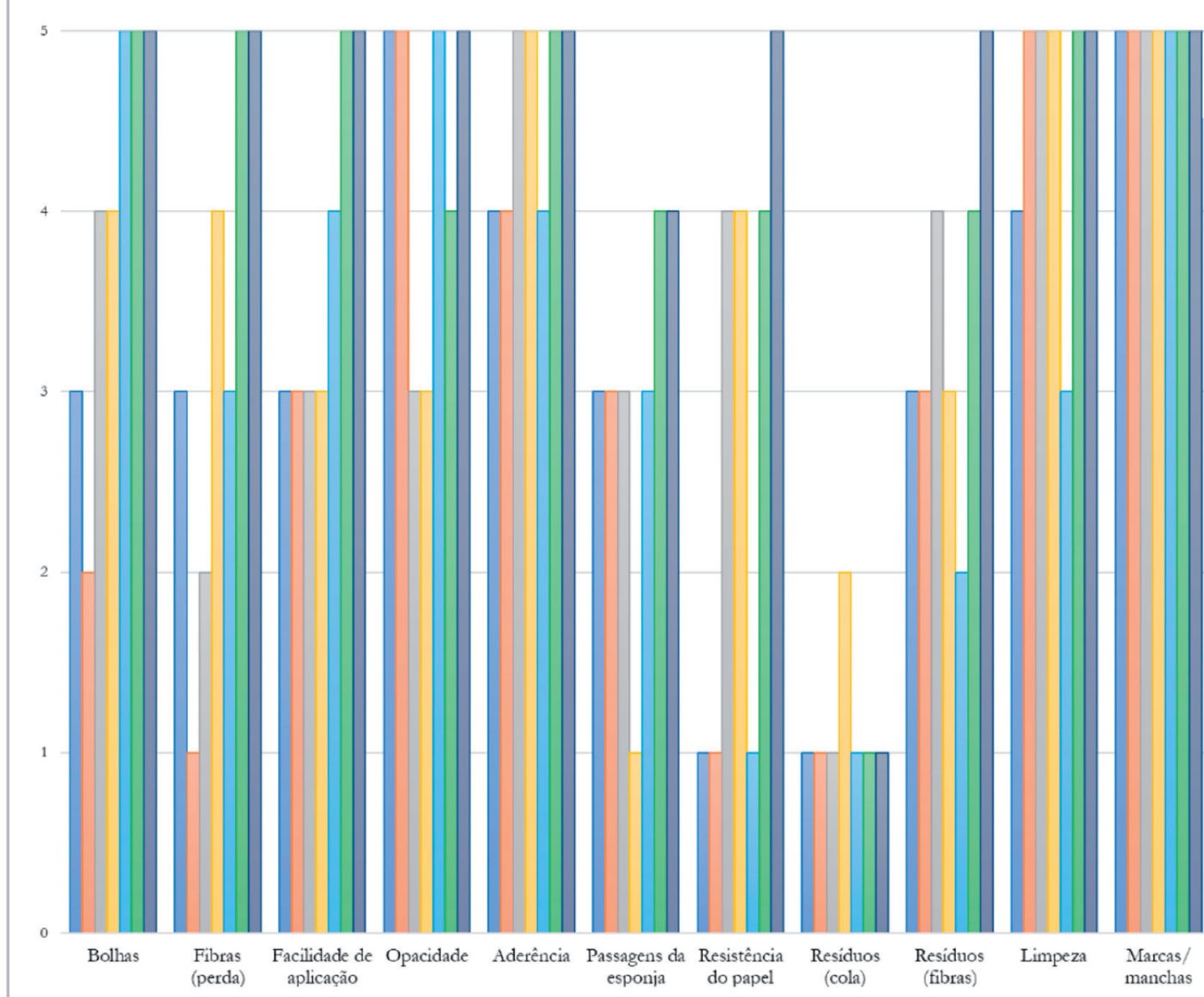

a)

$\square$ Gampi

$\square$ Mitsumata

$\square$ Tosa Usushi

$\square$ Kinugawa Elfenbein

$\square$ Bib Tengujo

$\square$ Modelspan

口Wet Strength Tissue

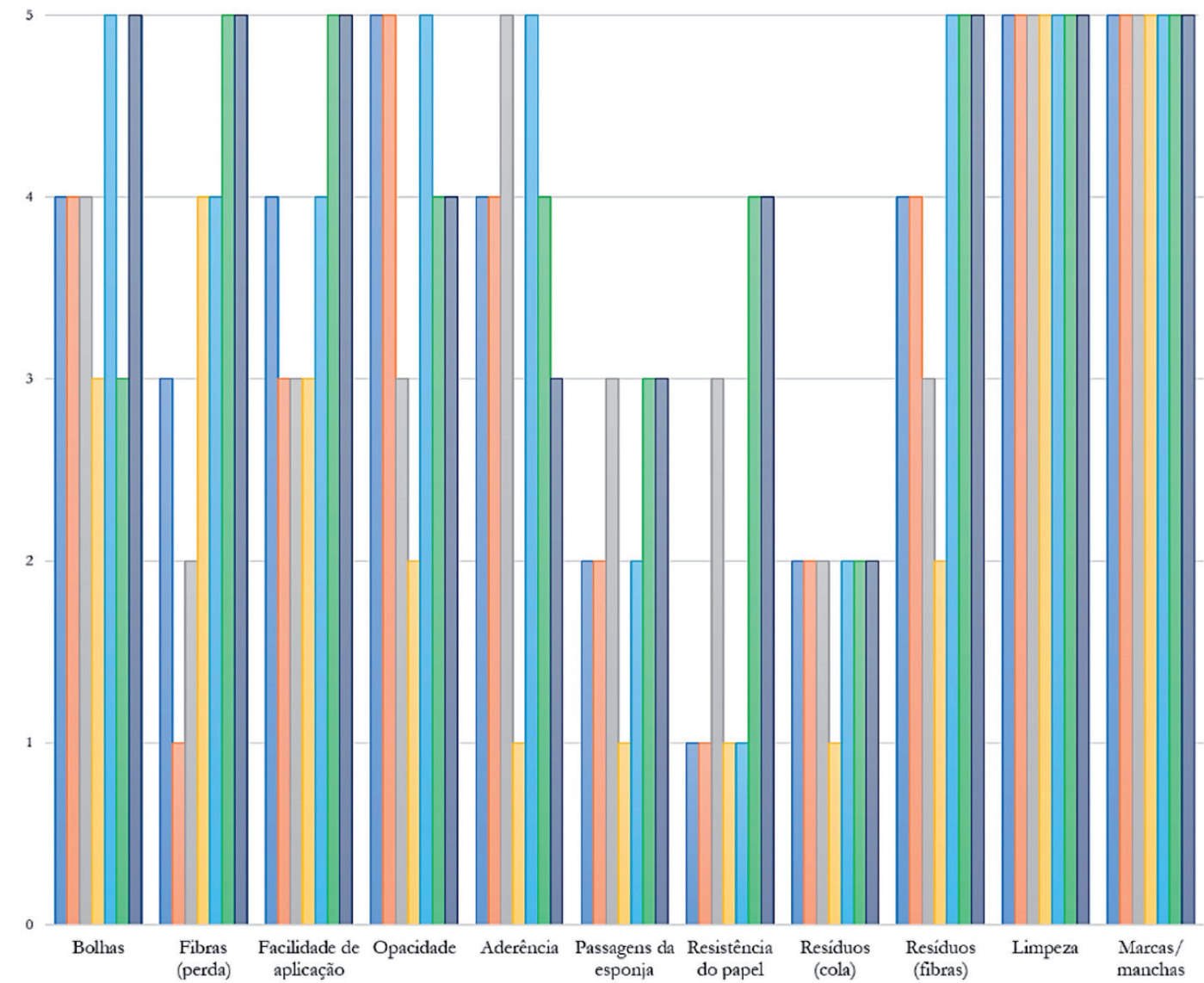

b)

口Gampi

$\square$ Mitsumata

$\square$ Tosa Usushi

Kinugawa Elfenbein

Bib Tengujo

$\square$ Modelspan

口Wet Strength Tissue

Figura 6.- Resultados obtidos para cada um dos papéis na combinação de cola de coelho com as texturas a) lisa, b) com empastamentos. Patrícia Varela@ 


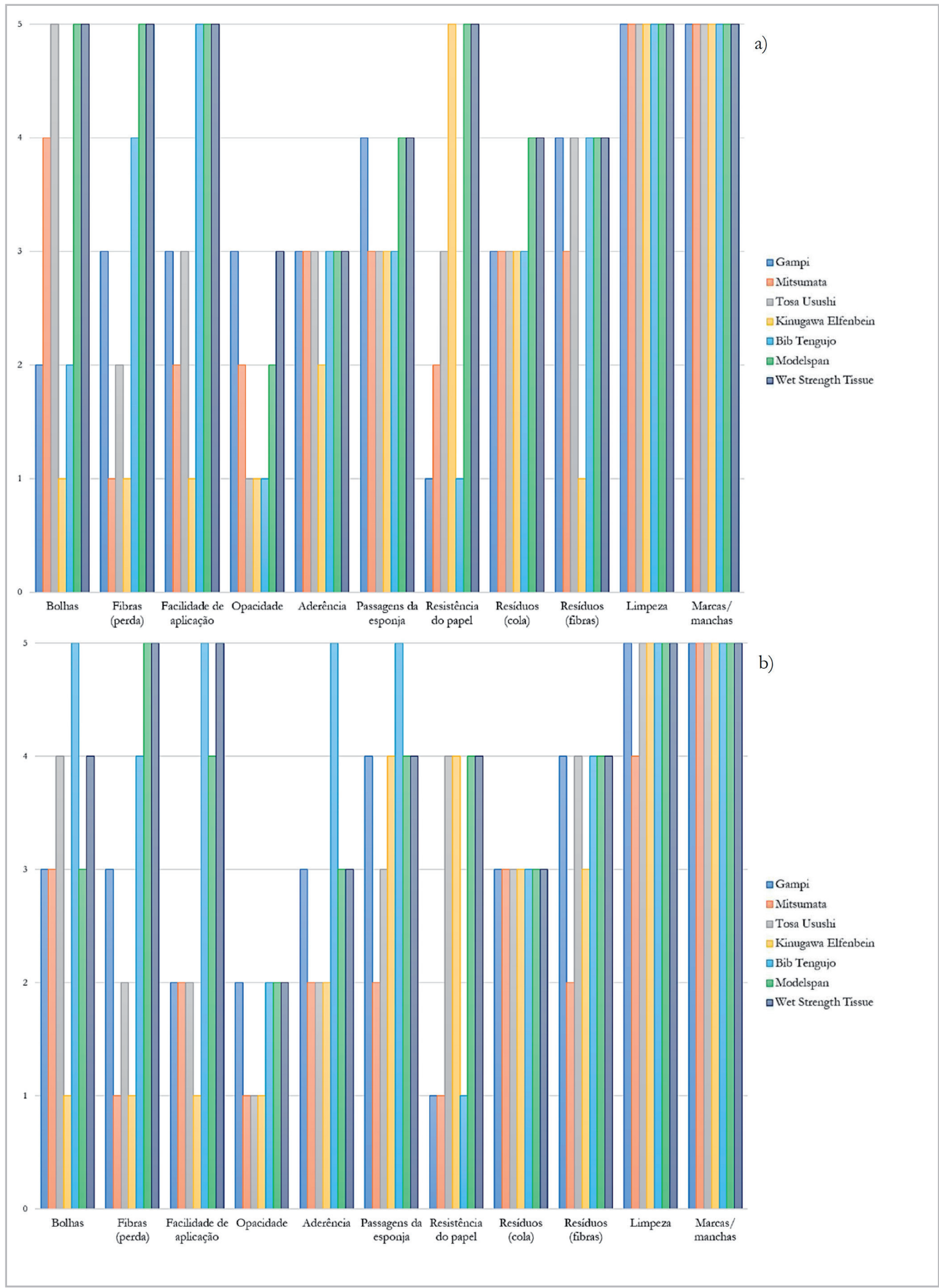

Figura 7.- Resultados obtidos para cada um dos papéis na combinação do adesivo Klucel ${ }^{\circledast}$ G com as texturas a) lisa, b) com empastamentos. Patrícia Varela@ 


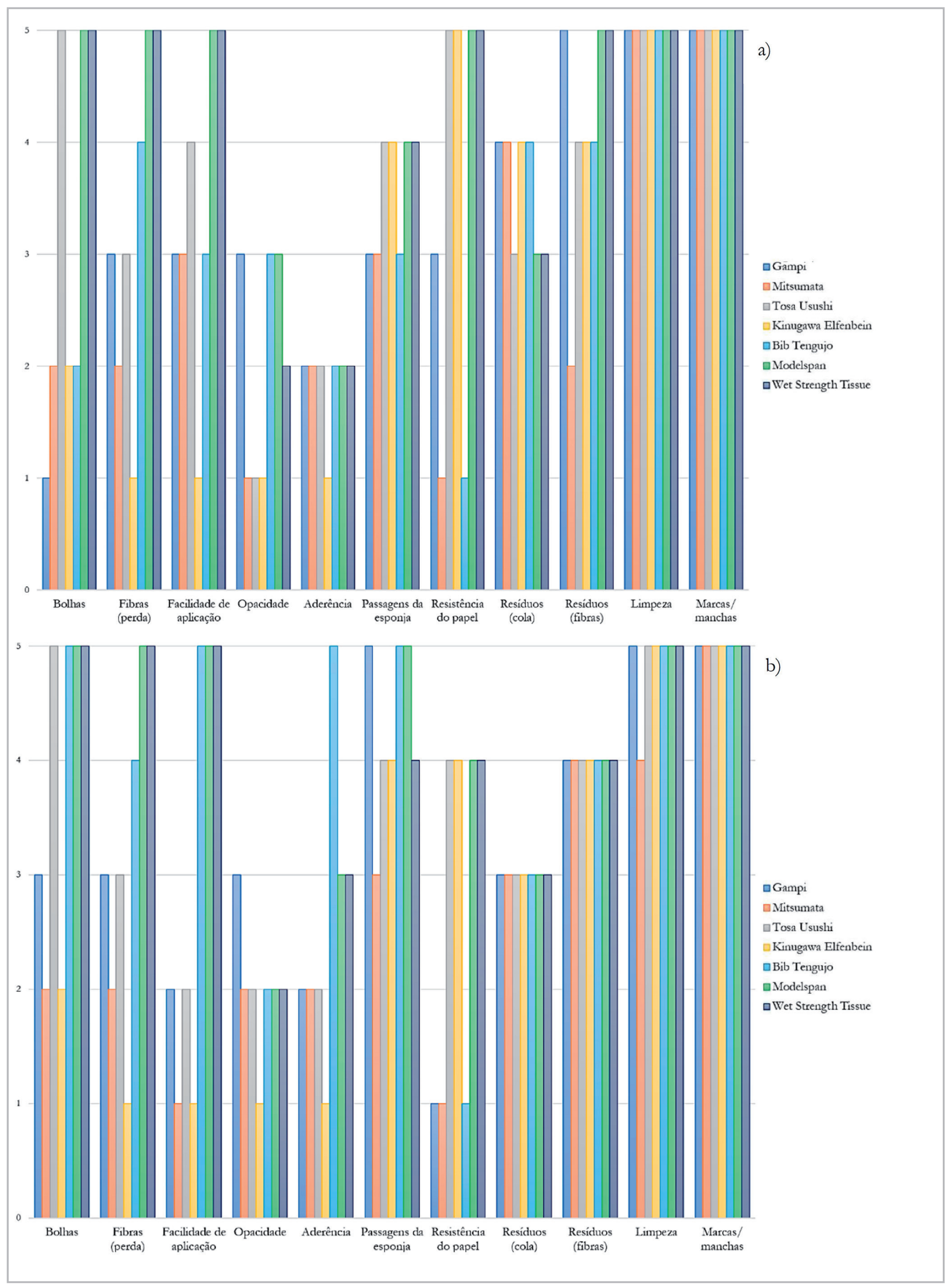

Figura 8.- Resultados obtidos para cada um dos papéis na combinação do adesivo Tylose ${ }^{\circledR} \mathrm{MH} 300$ com as texturas a) lisa, b) com empastamentos. Patrícia Varela@ 

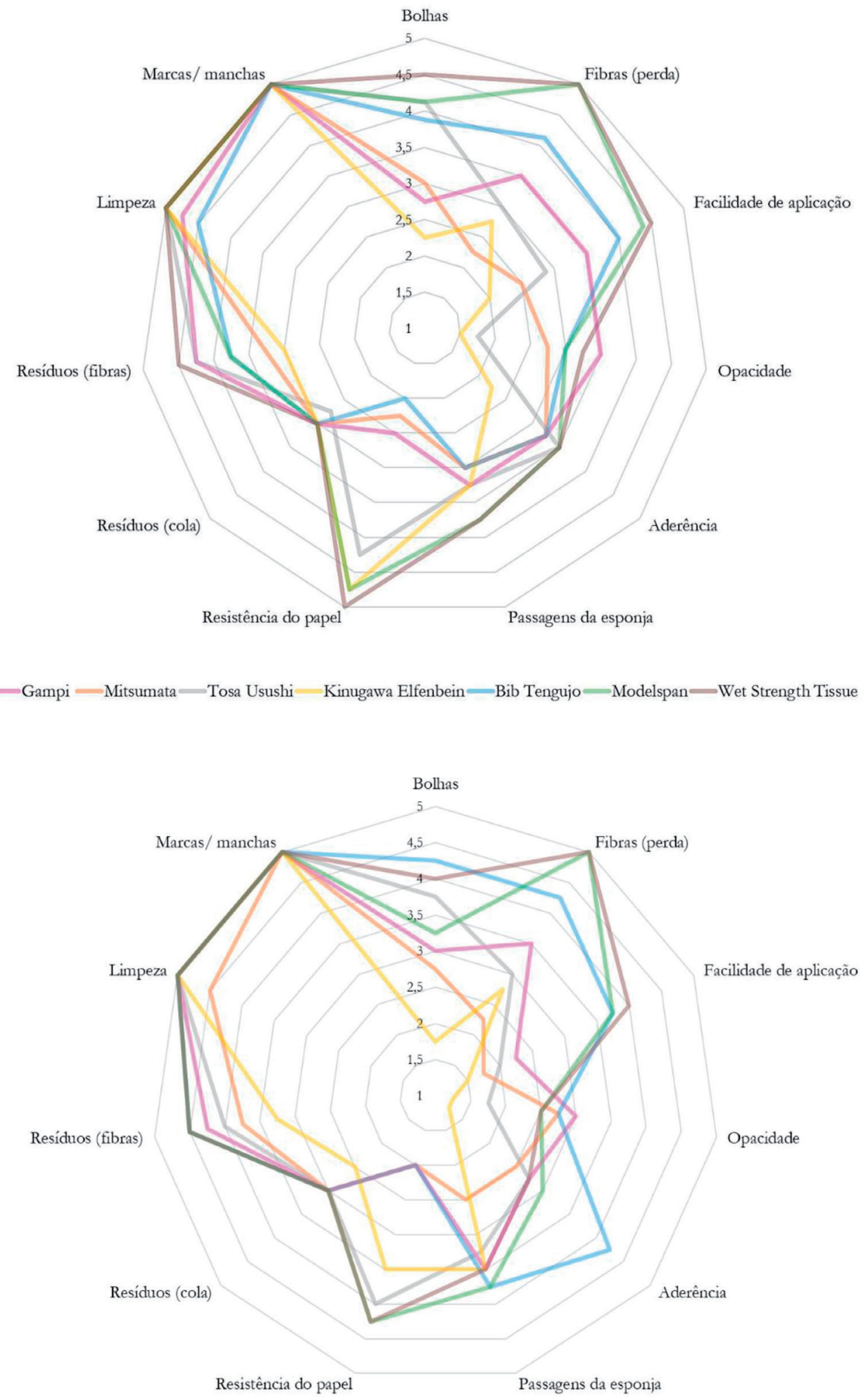

b)

- Gampi — Mitsumata — Tosa Usushi — Kinugawa Elfenbein — Bib Tengujo — Modelspan — Wet Strength Tissue

Figura 9.- Média do comportamento de cada papel com todos os adesivos para as texturas a) lisa, b) com empastamentos. Patrícia Varela@ 


\begin{tabular}{|c|c|c|c|c|c|c|c|c|}
\hline & & Gampi & Mitsumata & Bib Tengujo & Modelspan & $\begin{array}{l}\text { Wet-strength } \\
\text { Tissue }\end{array}$ & Tosa Usushi & $\begin{array}{l}\text { Kinugawa } \\
\text { Elfenbein }\end{array}$ \\
\hline \multirow{4}{*}{ Liso } & $B^{\prime} E V A^{\oplus} 371$ & & & & & & & \\
\hline & Cola de coelho & & & & $x$ & $x$ & & \\
\hline & Klucel $^{\circledR} \mathrm{G}$ & & & & & & & \\
\hline & Tylose $^{\circledast} \mathrm{MH} 300$ & & & & & & $x$ & \\
\hline \multirow{4}{*}{ Empastamentos } & BEVA $^{\circledast} 371$ & & & & & & & \\
\hline & Cola de coelho & & & $x$ & $x$ & $x$ & & \\
\hline & Klucel $^{\circledR}$ G & & & & & & & \\
\hline & $\begin{array}{c}\text { Tylose }^{\oplus} \mathrm{MH} \\
300\end{array}$ & & & & & & & \\
\hline
\end{tabular}

Tabela 2.- Indicação daqueles que, pelos resultados obtidos, são os melhores conjuntos papel/adesivo, em textura lisa e com empastamentos. Patrícia Varela@

\section{- limitações e pesquisa futura}

Uma das limitações iniciais desta investigação foi a dificuldade em encontrar papéis japoneses com a sua composição e método de fabrico (manual ou industrial) discriminados. Isto comprova que não existe consciencialização para o facto de que a matéria-prima utilizada e o método de produção dos papéis pode ser de grande relevância quando aplicada em certos tipos de tratamento.

Outra limitação encontrada foi a reduzida disponibilidade, em lojas físicas, de diferentes papéis japoneses que, na maioria dos casos, não apresentavam a sua composição. Por esta razão, houve a necessidade de aquisição do material através de sites da internet, que muitas vezes também não possuíam a composição ou não tinham os papéis em stock (por não serem muito vendidos). Apesar de terem sido procurados papéis com diferentes gramagens e composições, acabou por se verificar que os mais utilizados e, por isso, mais facilmente disponíveis, eram quase sempre os mesmos, tendo-se optado por sete papéis com composições e gramagens distintas.

Seria importante ter-se testado os diferentes papéis numa mesma gramagem, de modo a conhecer isoladamente as diferenças de comportamento das fibras. Por outro lado, seria igualmente relevante testar-se o mesmo papel com diferentes gramagens com vista a compreender detalhadamente quais os efeitos de uma diminuição ou aumento de gramagem. No entanto, não foi possível encontrar diferentes papéis com gramagens iguais, nem uma grande variedade de gramagens para cada fibra. Isto foi uma limitação, no sentido em que, sem testar todas estas soluções de gramagens para cada

papel não foi possível perceber exatamente se um comportamento se devia à gramagem ou à fibra do papel.

Inicialmente fez-se um balanço entre a utilização de pinturas já existentes e a criação de maquetes para testar os papéis. Optou-se pela construção de maquetes, uma vez que essa solução permitia evitar os danos que poderia acarretar a utilização de uma pintura preexistente e, por outro lado, possibilitava o teste dos diferentes papéis numa única superfície. Poderia ser uma boa opção, no futuro, realizar o facing em pinturas preexistentes utilizando apenas um papel em cada pintura. No entanto, para isso, será necessária uma grande quantidade de pinturas nas mesmas condições e de papéis.

A realização de maquetes teve um lado negativo, uma vez que o facto de estarem ainda muito frescas fez com que, depois de removido o facing, fossem percetíveis marcas onde os quadrados dos papéis aderiram. O óleo tem um processo de secagem lento. Embora os autores estivessem conscientes desta característica, o tempo e as condições disponibilizadas para o projeto não permitiram aguardar pela secagem do óleo ou pela secagem artificial do mesmo.

A aquisição de materiais foi também uma limitação uma vez que a compra de papéis, tintas, telas e adesivos implicava custo. Assim, foi necessário fazer uma escolha muito racional de quais os materiais a testar, para que se conseguisse cumprir com o orçamento para a execução deste estudo.

Através dos resultados constatou-se que certos papéis tinham maus comportamentos com alguns adesivos e bons com outros. Desta forma considera-se, como pesquisa futura, o desenvolvimento de testes com outros adesivos para além dos testados. Uma vez que, podem existir outras alternativas melhores que as testadas.

Uma última recomendação de pesquisa futura, que contribuiria em muito para este tema, seria o teste de um maior número de papéis japoneses e de outros tipos de papéis no facing.

\section{Conclusão}

Esta investigação teve como objetivo principal perceber qual o papel japonês mais adequado ao facing de pintura a óleo sobre tela. 
Para tal, foram realizadas maquetes, em três cores (preto, branco e azul), com duas texturas diferentes (lisa e com empastamentos), dois vernizes distintos (Laropal ${ }^{\circledR}$ A81 e 004 Retouching Varnish da Talens) e uma zona sem verniz. Fez-se a aplicação de diferentes cores para avaliar o comportamento dos distintos pigmentos nos adesivos e aos solventes selecionados. Não se verificou o aparecimento de marcas/manchas, a não ser a delimitação das áreas onde estiveram os papéis devido à curta secagem das tintas utilizadas para os ensaios. A utilização de diferentes texturas e vernizes, tinha por objetivo analisar o comportamento dos diferentes papéis e averiguar se existe um tipo de papel mais adequado a cada textura ou verniz. Neste caso, encontraram-se algumas diferenças significativas, como se verá adiante.

Nas maquetes foram testados seis papéis japoneses Gampi, Mistsumata, Tosa Usushi, Kinugawa Elfenbein, Bib Tengujo, Moldelspan - e ainda uma alternativa ao papel japonês - Wet-strength Tissue. Estes papéis foram testados com quatro adesivos (BEVA ${ }^{\circledast} 371$, cola de coelho, Klucel $^{\circledR} \mathrm{G}$ e Tylose $\left.{ }^{\circledR} \mathrm{MH} 300\right)$.

O objetivo foi que, em cada uma das combinações de materiais presentes na maquete, se testassem os 7 papéis com os 4 adesivos.

Através desta experiência conseguiu perceber-se que existem grandes diferenças relativamente aos papéis, texturas e adesivos:

- Quando utilizado o adesivo $B E V A^{\circledR} 371$, em todos os papéis, notou-se uma grande opacidade, impossibilitando verificar possíveis alterações na superfície pictórica, após aplicação do facing. O mesmo ocorreu com os adesivos Klucel $^{\circledR} \mathrm{G}$ e Tylose ${ }^{\circledR}$ $\mathrm{MH}$ 300, sendo que, no primeiro, era mais evidente com os papéis Tosa Usushi, Kinugawa Elfenbein e Bib Tengujo. Neste aspeto, a cola de coelho teve um bom desempenho, possibilitando uma boa perceção da camada pictórica;

- Nas zonas de empastamentos, o adesivo BEVA ${ }^{\circledR} 371$ não fez aderir o papel à superfície da pintura;

- Na maior parte dos casos, o papel Kinugawa Elfenbein teve resultados menos positivos. Com os adesivos BEVA $^{\circledR} 371$, Klucel $^{\circledR} \mathrm{G}$ e Tylose ${ }^{\circledR} \mathrm{MH} 300$ tem-se uma aderência muito fraca. Sendo possível fazer a remoção do facing manualmente, sem utilização de qualquer solvente. O mau comportamento deste papel, quando associado aos dois últimos adesivos, talvez se deva à grande viscosidade dos mesmos que, em combinação com a alta gramagem do papel $\left(22 \mathrm{~g} / \mathrm{m}^{2}\right)$, poderá não ter possibilitado uma boa absorção. Apesar de tudo, este papel teve bom comportamento, nas zonas lisas, quando aplicado com cola de coelho, aderindo muito bem à superfície e deixando poucos resíduos. O mesmo não se aplica às zonas de empastamentos, uma vez que a forte aderência requereu o exercício de muita força nas passagens da esponja, correndo-se assim o risco de destacamento dos empastamentos;
- O Gampi e o Mitsumata mostraram ser pouco resistentes, rasgando bastante durante a remoção, dificultando assim o trabalho de limpeza. Devido à sua grande perda de fibras durante a passagem do pincel com adesivo, o Mitsumata desfaz-se muito, formando, por vezes, buracos no papel;

- O Tosa Usushi demonstrou ser apropriado em aplicações com o adesivo Tylose ${ }^{\circledR}$ MH 300 em zonas lisas;

- O Wet-strengh Tissue e o Modelspan revelaram ser, em quase todas as situações, os melhores papéis nas zonas lisas. Isto deve-se à sua facilidade de aplicação, com pouca perda de fibras e sem formação de bolhas, à boa aderência e à facilidade de remoção;

- Nas zonas de empastamentos, o Bib Tengujo teve o melhor comportamento, uma vez que a sua aderência aos empastamentos mais altos ( $\geq 3 \mathrm{~mm}$ ), sem formação de bolhas, foi perfeita. Relativamente aos empastamentos mais baixos ( $<3 \mathrm{~mm})$, o Wet-strength Tissue e o Modelspan são, mais uma vez os melhores, já que têm vantagem, em relação ao Bib Tengujo, de serem removidos facilmente, rasgando muito pouco.

É de salientar que, apesar de terem sido testadas todas as combinações de materiais presentes na maquete (cores, vernizes/zona sem verniz e texturas) com todos os papéis e adesivos, não foram feitas quaisquer referências a diferenças de resultados para os diferentes vernizes/ zonas sem verniz e para as diferentes cores, uma vez que os resultados não apresentaram diferenças significativas quando aplicado o facing. No entanto, os resultados exibidos correspondem a todos os vernizes/zona sem verniz e a todas as cores.

Em geral, a limpeza de resíduos foi muito simples para todos os papéis e adesivos, não havendo marcas ou manchas relacionadas com estes.

Em média, para a textura lisa, o Wet-strength Tissue teve o melhor desempenho, obtendo valores bastante elevados para as variáveis "bolhas", "perda de fibras", "facilidade de aplicação", "resistência do papel", "resíduos de fibras", "limpeza" e"marcas/manchas".

No que diz respeito às zonas de empastamentos, destacaram-se três papéis: Bib Tengujo, Wet-strength Tissue e Modelspan. Sendo que o primeiro se destaca em zonas de empastamentos mais altos e os restantes em empastamentos mais baixos.

Desta feita, podemos concluir que, nos casos expostos, o papel japonês nem sempre foi o mais indicado, uma vez que o Wet-strength Tissue se revelou o mais competente em certas situações.

Os resultados obtidos validam ainda as espectativas de que pode existir um papel mais adequado a cada situação.

Em virtude do que foi mencionado espera-se ter 
contribuído para a melhoria do conhecimento acerca da utilização dos papéis japoneses no facing. Espera-se ainda que futuras investigações possam levar ainda mais além os conhecimentos aqui adquiridos.

\section{Notas}

[1] Terminologia inglesa utilizada pela maioria dos profissionais da área de conservação e restauro em Portugal. Por esse motivo será este o termo utilizado ao longo do artigo.

[2] As tintas utilizadas resultavam da mistura de pigmentos. Nenhum continha o pigmento puro. Por este motivo, indica-se os pigmentos presentes em cada tubo de tinta a óleo Sennelier. O PBk9 é o Negro de Marfim, e o PBk7 o Negro de Carbono. Ref. The Color of Art Pigment database. Disponível em: http://www. artiscreation.com/ [Consultado a 16/09/2019].

[3] Tinta constituída por Branco de Titânio (PW6) e Branco de Zinco (PW4). Ref. The Color of Art Pigment database. Disponível em: http://www.artiscreation.com/ [Consultado a 16/09/2019].

[4] Tinta constituída por Azul Ultramarino (PB29), Azul de Ftalocianina (tendência verde) e o Branco de Titânio (PW6). Ref. The Color of Art Pigment database. Disponível em: http://www. artiscreation.com/ [Consultado a 16/09/2019].

[5] Calandragem é o nome dado ao processo de conformação plana de materiais através de cilindros.

[6] Os produtores de colas animais classificam-nas segundo a sua força de gel - Bloom, ou gramas Bloom. Quanto maior for este fator, mais resistente será o adesivo.

\section{Referências}

ALBA, P., MARTíN-REY, S., DOMÉNECH-CARBÓ, M. (2019). “Analysis of facing materials used as remoistenable temporary support for facing on canvas paintings", Ceroart Journal. https://doi. org/10.4000/ceroart.6532 [consultado 08/08/2019].

CALVO, A. (2002). Conservación y restauración de pintura sobre lienzo. Barcelona: Ediciones del Serbal.

COLBOURNE, J., HORI, M. (2015). "Modern machine-made washi and the implications for contemporary conservation practice", Adapt \& Evolve, 158-167. https://icon.org.uk/node/4998 [consultado 10/01/2019].

DORIA, M. (2013). "Requiem o Recupero Critico dei Metodi di Foderatura Tradizionali". Atti del XI Congresso Nazionale IGII, 7791. http://cbccoop.it/pubblicazione/requiem-o-recupero-criticodei-metodi-di-foderatura-tradizionali/ [consultado 10/11/2018].

FUGUEL, I. (2016). Uma Breve História do Livro. São Paulo: Edição do Autor. https://bit.ly/2Sk7Nsc [Consultado 30/11/2018].
GIANNINI, C., ROANI, R. (2008). Diccionario de restauración y diagnístico. Donostia-San Sebastián: Nerea.

GRANTHAM, S. (2002). "Japanese Handmade Paper: Plant Fibers, Paper Making Methods, Names and Usage", Papier Restaurierung. 3: 29-34.

MASUDA, K. (2010). "Japanese Paper and Kyōgo", The Paper Conservator. 9: 32-41.

MIZUMARA, M., KUBO, T., MORIKI, T. (2015). "Japanese paper: History, development and use in Western paper conservation", Proceedings from the International Conference of the Icon Book \& Paper Group, 43-59. https://icon.org.uk/system/files/public/ Publications/AandE15/4-ae15 mizumura 43-59.pdf [Consultado 01/12/2018].

NICOLA, G., NICOLA, G., ARODIO, R. (1973). "A New Facing Material", Studies in Conservation. Vol. XVIII, No 4:177-179.

SÁNCHEZ, A. (2012). Restauración de Obras de Arte: Pintura de Caballete. Madrid: Aka Bellas Artes.

RODGERS, S. (1988). "Consolidation/Fixing/Facing", Paper Conservation Catalog ( $5^{\mathrm{a}}$ ed.).

STONER, J., RUSHFIELD, R. (2012). Conservation of Easel Paintings. Nova lorque: Routledge.

VILLARQUIDE, A. (2005). La pintura sobre tela II: Alteraciones, materiales, y tratamientos de restauración. San Bartolomé: Nerea.

WADA, M. (2008). “Técnicas, elaboración e importancia del «neri» en el proceso de fabricación de papel japonés de Ogawa-machi", Pátina. 15: 55-7.

\section{Autor/es}

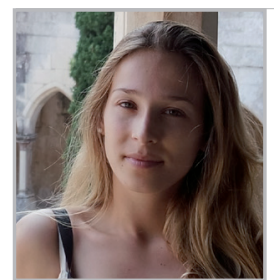

\section{Patrícia Varela}

patriciasfvarela.94@gmail.com

Faculdade de Belas-Artes, Largo da Academia Nacional de Belas-Artes, Lisboa, Portugal https://orcid.org/0000-0002-2165-0761

Licenciada em Património Cultural e Arqueologia em 2017, pela Universidade do Algarve e mestre em Ciências da Conservação, Restauro e Produção de Arte Contemporânea em 2020, pela Faculdade de Belas-artes da Universidade de Lisboa. Estagiou no Museu Municipal de Faro em Conservação e Restauro. A investigação de mestrado foi acerca da utilização de diferentes papéis japoneses no facing de pintura a óleo sobre tela, feita em colaboração com a Professora Ana Bailão e o Professor Matteo Rossi Doria, na empresa Conservazione di Beni Culturali, em Roma. Atualmente trabalha na área da conservação e restauro. 


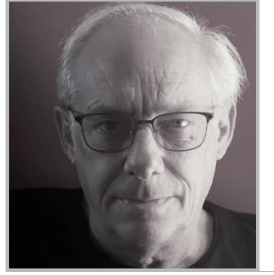

\section{Matteo Rosi Doria}

mat.rossidoria@gmail.com

CBC Conservazione Beni Culturali, Viale

Manzoni, Roma, Itália

https://orcid.org/0000-0002-3830-4304

Matteo is in conservation since 1979. After a three years apprenticeship and ICCROM training he dedicated his professional interest to few specific problems in conservation, first of all canvas paintings structural conservation. He always tried to put things together, different methods and approaches, looking at an honest assessment of each of them and revisit traditional methods recipes and applications. Meanwhile he worked in other fields of research, as paint layers consolidation and minimal treatments, in Cesmar7 international meeting organization (2004-2006-2008). Matteo does also work on historical carriage collection conservation/restoration, preventive conservation, in national and European Community projects, as project manager in training/update projects and events, teaching and lecturing for Viterbo University and other institutions. He's member of CBC Conservazione Beni Culturali, a large private company settled in Roma.

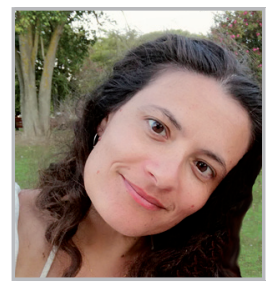

\section{Ana Bailão}

ana.bailao@gmail.com

Centro de Investigação e de Estudos em Belas-Artes (CIEBA), Lisboa, Portugall

https://orcid.org/0000-0002-2652-0843

Prof. Auxiliar da Faculdade de Belas-Artes da Universidade de Lisboa. Coordenadora do Mestrado de Ciências da Conservação, Restauro e Produção de Arte Contemporânea na mesma instituição. Licenciada em Conservação e Restauro pelo Instituto Politécnico de Tomar (2005) e mestre em Conservação de Pintura pela Universidade Católica Portuguesa (2010). Doutora em Conservação de Bens Culturais pela mesma universidade, em colaboração com o Centro de Investigação em Ciência e Tecnologia das Artes (CITAR) e o Instituto do Patrimônio Cultural de Espanha (IPCE), em Madrid. Investigações e projetos foram apresentados através de publicações, palestras, exposições e apresentações. Ensino de conservação e restauro desde 2008. Intervenções de conservação e restauro para privados e Estado desde 2004.
Artículo enviado el 04/10/2021

Artículo aceptado el 08/10/2021

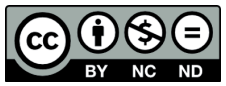

https://doi.org/10.37558/gec.v20i.1066 